\title{
Fundamentalisme Agama dan Dahaga Spiritualitas Manusia Modern
}

\author{
Agus Triyanta
}

Fundamentalism, as has been proved by many researchers, does not only occur in Islam. Almost all of religion across the world may be potential to be locus of fundamentalism. The Issue of fundamentalism is getting populer recently. This because there are a lot of political cases and social unrests relate with "fundamentalism behaviour". Here, are examired factors that cause the rise of fundamentalism, especially relates with the need for spirituality among modern people.

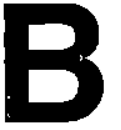

ukan hanya pasca "the Eleventh September Bombing" saja term fundamentalisme ini mengemuka dalam wacana sosial politik internasional. Meski dengan gradasi penekanan yang berbeda, isu ini mulai populer -minimal dalam dunia Islam - sejak terjadinya Revolusi Iran 11 Pebruaru 1979 di bawah komando para mullah, elite agamawan dalam madzhab Syi'ah, lebih khusus lagi Syi' ah Imamiyyah yang pucuk pimpinannya dipegang oleh Imam Khomeini. Disusul kemudian, dengan munculnya rezim Thaliban pada dekade terakhir dari abad keduapuluh. Maka, setelah pemboman di WTC itu, isu ini mendapatkan kembali momentumnya, dan kemudian, isu ini seakan tidak akan pernah kehilangan signifikansi untuk dibahas dari berbagai segi. Terlebih, kondisi Indonesia saat ini sedang mendapat sorotan dunia karena 'dugaan' adanya jaringan terorisme internasional, $\mathrm{di}$ samping memang, Indonesia ini kaya juga dengan berbagai madzhab, aliran atau bahkan sekte keagamaan (Islam).

Artikel ini ini termasuk di antara sekian banyak upaya untuk menyoroti bagaimana fundamentalisme itu timbul. Fokus utamanya adalah mencari segi pertautan antara fundamentalisme dengan pemenuhan kebutuhan spiritualitas manusia. Dimulai dengan klarifikasi masalah fundamentalisme, pembahasan kemudian dilanjutkan dengan menyoroti seputar kebutuhan manusia modern akan kebutuhan spiritualitas. Bagian selanjutnya akan menganalisis berbagai akibat yang muncul atas kegersangan spiritualitas, yang kemudian akan berlanjut pada munculnya berbagai bentuk dan model gerakan keagamaan alternatif 
sebagai upaya jawaban atas kebutuhan spiritualitas tersebut. Terakhir, dibahas kecenderungan gerakan keagamaan yang timbul tersebut untuk berperilaku sebagai gerakan fundamentalisme.

\section{Fundamentalisme dalam Lintas Agama}

Fundamentalisme, temyata bukan hanya monopoli agama tertentu, bukan Islam, Kristen, Budha, ataupun agama lain. Namun, hampir pada setiap agama memiliki potensi untuk melahirkan fundamentalisme, meski fundamentalisme itu hanya sebagai sempalan dari berbagai agama yang telah mapan. Mungkin orang akan dengan serta merta mengatakan bahwa fundamentalisme itu identik dengan Islam jika melihat perilaku pejuang HAMMAS atau perjuangan Palestina garis keras yang lain, meledakkan "bom bunuh diri' yang selain membunuh dirinya, juga menghancurkan bangunan serta menyisakan korban rakyat sipil.

Namun, ternyata, orang akhimya harus mengakui bahwa pemboman di Oklahoma 1995, yang merusakkan bangunan dan membunuh rakyat sipil itu, dilakukan oleh seorang Mc Veigh, yang melakukan itu semua karena terinspirasi oleh selebaran The Patriot Report dari aliran agama Christian Identity cabang Arkansas, sebuah sekte/ gerakan yang pada tahun 1996 melakukan pemboman Olimpiade Atlanta dan tahun 1999 menembaki sebuah tempat penitipan anak Yahudi." Sama halnya, orang juga harus mengerti bahwa yang melakukan pembunuhan massal dengan menyebarkan gas sarin di sebuah subwaydi Tokyo tahun 1995, dan membunuh 12 orang dan melukai 5.500 orang, adalah anak buah Shoko Asahara, pemimpin sebuah sekte keagamaan berakar pada agama Jepang (dekat dengan Budhdha-Konghuchu) yang bemama Aum Shinri Kyo. ${ }^{2}$
Intinya adalah, bahwa fundamentalisme bukan hanya monopoli Islam atau agama tertentu yang lain, namun, furidamentalisme memiliki akar dalam berbagai agama atau tradisi keagamaan. Haralambos dan Holbom mencatat, bahwa fundamentalisme bisa teridentifikasi dari berbagai agama di seluruh dunia; termasuk fundamentalisme kaum Sikh di Punjab, fundamentalisme kaum Hindi Srilangka di Inggris, fundmentalisme Islam di Turki, serta fundamentalisme di kalangan Protestan yang ada di Irlandia, Scotlandia dan USA. ${ }^{3}$ Dengan kata lain, sekte-sekte atau aliran-aliran tertentu yang kemudian menjurus pada bentuk sebuah aliran fundamentalis, bisa saja merupakan modifikasi dari sebuah agama, sebagaimana yang nati akan dibahas di depan.

Lantas, apa dan bagaimanakah fundamentalaisme itu? Richard Kennedy mendefinisikan fundamentalisme dengan, "a movement in Protentantism which first became influential at the beginning of the twentieth century as a reply to Darwinism, the growth of science and Darwinism in general." Bahkan, masih menurut Kennedy, gerakan fundamentalisme semacam ini yang paling kuat di Amerika biasanya disertaj dengan tindakan menyalahkan Katholik Roma dan berbagai bentuk pemikiran modern. Definisi ini mengindikasikan bahwa fundamentalisme itu bernuansa semangat perlawanan terhadap munculnya penemuan-penemuan (termasuk teori

'Goenawan Mohamad, 'Oklahoma', dalam, Tempo, 20 Januari 2002

${ }^{2}$ Republika, 19 Mei, 1995

${ }^{3}$ Haralambos, Michael \& Holborn, Martin, Sociology, Themes and Perspectives (London: Collins Educational, 1999) h.458.

${ }^{4}$ Kennedy, Richard, The Dictionary of Beliefs (London: Ward Lock Educational, 1984) h.77. 
Darwin) yang dipandang menyerang agama dan tradisi yang telah mapan. Sedangkan, menurut Karen Amstrong, fundamentalisme adalah sebuatan untuk "the militant form of piety", yakni sebuah bentuk ketaatan yang sangat militan. ${ }^{5}$ T.N. Madan, dalam Characteristics of Sikh Fundamentalism, menegaskan kesan fundamentalisme selain sebagai "broad sense of insistence on certain basic beliefs and practices" juga sebagai "a forceful affirmation of religious faith and cultural identity, combined with a militant pursuit of secular interests". Di sini, fundamentalisme lebih dimaknakan sebagai memegang erat ajaran, kepercayaan atau amalan tertentu, selain juga memiliki karakter yang khas, mengunggulkan kebenaran agama dan identitas kultur tertentu seraya melawan kepentingan duniawi. ${ }^{6}$

Suatu hal yang bisa disimpulkan dari terminologi fundamentalisma adalah bawah istilah ini berkonotasi pada sebuah bentuk penganutan dan pemegangan secara sangat erat terhadap sebuah ajaran dan kepercayaan tertentu, berikut ritus-ritus amaliah yang dituntunkannya, seraya, melakukan berbagai bentuk perlawanan secara gigih dan keras terhadap nilai-nilai dunia materialistis yang dipandang mengancam kelanggengan keyakinannya tersebut. Dari itu bisa dimengerti, mengapa gerakan fundamentalisme itu dipandang sangat membahayakan, tentu saja karena di situ ada nilai, 'perlawanan tanpa kompromi' terhadap sesuatu yang telah dinilainya sebagai ancaman bagi mereka dan ajaran mereka.

Permasalahan pokoknya kemudian adalah bahwa fundamentalisme, jika itu terjadi terhadap sebuah prinsip yang kebenarannya diakui secara universal, akan tidak mengakibatkan banyak masalah karena musuh fundamentalisme tersebut adalah juga musuh bagi setiap orang. Namun, yang menjadi masalah adalah bahwa apabila fundamentalisme itu terjadi dalam tingkat ekslusifitas yang tinggi dengan menafikan proses dialog dan persuasi sehingga 'keputusan' apakah sesuatu itu dianggap ancaman atau bukan hanya terletak pada tangan mereka (penganut sebuah ajaran), ini sangat mungkin akan digunakan oleh seseorang sebagai alat kepentingan tertentu.

Sehingga, dalam kaitannya dengan dahaga spiritualitas manusia modern ini, ada semacam kecenderungan, sebagai yang nanti akan diungkap, bahwa kegersangan spiritualitas akan menorong orang untuk menemukan nilai ajaran tertentu yang bisa dijadikan pijakan dan pegangan di tengah ketidakpastian dan labilitas kehidupan modem. Karenanya, ini acapkali mendorong orang tersebut untuk mendapatkan sebuah ajaran dengan tanpa banyak pertanyaan dalam pencariannya. Akhirnya, banyak di antaranya 'terjebak' pada mengikuti aliran, sekte atau ajaran yang ternyata menanamkan fundamentalise dan menihilkan upaya dialog dan analisa kritis dalam menyelesajkan apa yang dianggap sebagai masalah dan ancaman. Dalam pembahasan berikut, akan disajikan, bagaimana kegersangan spiritualitas itu bisa terjadi, serta, mengapa manusia modern sangat merindukannya.

\section{Spiritualitas, Sebuah Kebutuhan Mendasar}

Sudah menjadi opini yang diterima secara umum, bahwa orang modem, dengan segala kegersangan hidupnya akhirnya memimpikan sebuah spiritualitas. Maka,

${ }^{5} \mathrm{Azra}, \mathrm{Azumardi}$, 'Karen Amstrong: Islam dalam Perspektif Empati', dalam Tempo, 30 Desember 2001.

${ }^{6}$ Madan,T.N., ' Characteristics of Sikh Fundamentalism' dalam Beckerlegge, Gwilym, The World Religious Reader (London: Routledge, 1998) h. 458. 
Topik: Fundamentalisme Agama dan Dahaga Spiritualitas Manusia Modern, Agus Triyanta

sebagaimana yang diungkap oleh sebagian futurolog, saat ini, ada sebuah trend besar pencarian terhadap spiritualitas. Orang sudah merasa chaos dan cemas karena rindunya terhadap spiritualitas. Modernitas dan kemajuan teknologi tidak bisa menjawab berbagai kebutuhan mereka, apa yang dikehendaki oleh hati mereka. Ada sesuatu yang telah hilang dari kehidupan manusia modern saat ini, dan kemudian, mencoba untuk menemukan spiritualitas dengan cara melacak jejak-jejak dan warisan tradisionalitas dan agama-agama lama. Spiritualitas bukan hanya memiliki relasi yang dekat dengan agama, akan tetapi, spiritualitas merpakan suatu essensi yang interlinked dengan agama. Sehingga, keinginan yang kuat manusia modern untuk meraih spiritualitas adalah juga merupakan 'kehausan' untuk mendapatkan agama, tentunya karena agama lah sesuatu yang selalu menjanjikan spiritualitas. Agaknya, begitulah jalan pemikiran yang akhirnya meniscayakan adanya kesimpulan selanjutnya yakni prediksi bahwa akan adanya kebangkitan yang dramatis dari berbagai agama dalam millenium ketiga ini.

Ada banyak data yang bisa mensupport berbagai alasan di atas. Saat ini, meskipun di dunia Timur juga banyak pranata sosial yang menawarkan spiritualitas, namun justeru di dunia Barat, banyak aliran spiritual dengan mudah dijumpai. Ada lebih dari 1000 sekte Kristiani dan 600 institusi agama alternatif yang bersaing untuk mendapatkan pengikut di Amerika pada tahun $1990 .{ }^{7}$ Sangat mungkin, keanggotaan formal dari beberapa agama yang telah mapan memang terlihat menurun, tetapi ini hanya merupakan representasi dari salah satu spketrum keagamaan, tidak bisa diartikan sebagai menurunnya sama sekali minat manusia terhadap agama. Dalam sisi yang lain, bisa dilihat secara faktual bahwa agama-agama berkembang dengan pesat di paruh kedua abad yang lalu di berbagai tempat, ada gerakan agama baru di kotakota di Jepang, di berbagai kampus di Amerika Serikat pada tahun 1960-an, adanya semangat yang keuat dari revivalimse Islam tahun 1970-an, dan bermunculannya agama-agama alternatif, atau gerakangerakan kharismatis di berbagai benua pada dekade 1970-an dan 1980-an.

Nilai spiritual akan sangat mempengaruhi orang (beragama) yang memegangi spitualitas tersebut. Itulah mengapa, dengan adanya dorongan spiritualitas tersebut, seseorang yang beragama akan bisa berbuat di luar perilaku manusia pada umumnya. Spiritualitas, ungkap Kuper, memberikan inspirasi pada manusia untuk betindak secara berani, untuk mempertahankan sesuatu dengan kuat, namun, kadang-kadang spiritualitas juga dipakai untuk menjustifikasi kekuasaan dan kepentingan politik. ${ }^{8}$

Suatu hal yang harus dipahami secara tepat kemudian adalah, apakah sebenarnya yang dimaksud dengan spiritualitas itu. Bukanlah sesuatu yang mudah untuk mendefinisikan spiritualitas secara tepat, bukan saja karena setiap agama memiliki cara-cara yang saling berbeda dalam hal pemenuhan spiritualitas, namun juga karena kata "spiritualitas" ini dipakai untuk lingkup perbincangan yang sangat luas.

Spiritualitas, antara lain didefinisikan sebagai" "sebuah upaya untuk menumbuhkan sensitifitas terhadap diri, orang lain, makhluk selain manusia, serta terhadap Tuhan; atau sebagai sebuah bentuk eks-

7Hinnels, John R, A New "Handbook of Living Religions (Oxford: Bluckwell Publisher, 1997) h. 598.

${ }^{6} \mathrm{Kuper}$, Adam, \& Kuper, Jessica, The Social Science Encyclopedia (London-New York: Routledge, 1996) h. 735 
plorasi terhadap apa saja yang berkenaan dengan hakekat manusia, pertanyaan mendasar tentang kemanusiaan yang utuh. ${ }^{9}$ Spiritualitas merupakan sesuatu yang bersifat kedalam diri, yang dilawankan dengan sesuatu yang bersifat material, fisikal, dan eksternal. Lebih dari itu, ini bukan ide akan sebuah konsep, tapi inilah relaita hidup yang bisa didapati sepanjang sejarah manusia, yang selalu bergaaung bersama kerinduan hati manusia terhadap kedamaian, kesenangan, rahmat, yang bersifat abadi dan permanen. Itulah yang telah telah menggoda manusia sepanjang masa, suatu hal yang oleh para penghuni planet ini senantiasa dicari-cari. Bukanlah suatu hal aneh, bila kebutuhan ini terhambat, manusia akan menempuh berbagai cara, termasuk caracara yang dipandang a-sosial untuk memenuhinya.

Dari pembahsan di atas, secara singkat, spiritualitas bisa didentifikasi sebagai sesuatu yang:

- kebutuhan di dalam hati (inner hart need)

- sesuatu yang bersifat abstrak yang berlawanan dengan material

- berkaitan dengan arti kehidupan, hakekat manusia, serta hubungan dengan Tuhan.

Tidak selunuh agama memiliki terminologi spiritualisme, istilah yang sebenarnya berasal dari tradisi Kristen. Namun bukan berarti agama lain tidak memiliki spiritualitas, sangat bisa jadi hanya karena berbeda istilah saja sedangkan secara essensial tetap sama. Spiritualitas adalah sebuah pattern yang akan ada pada setiap agama, meski dalam tingkat kandungan yang berbeda-beda antara sebuah agama dengan agama yang lain.

Untuk mendapatkan pemahaman yang lebih jelas, penting di sini diberikan definisi juga tentang agama, minimal agar tidak terjadi overlapping antara agama dan spiritualitas. Agama, ungkap Rudely Otto adalah kesatuan dari sistem kepercayaan dan prakek yang dikaitkan dengan keberadaan segela sesuatu, alam semesta, supernatural dan ke-ilahian'. ${ }^{10}$

Berdasarkan uraian tersebut, dapatlah kemudian ditarik garis perbedaan antara gama dan spiritualitas; agama jelas lebih luas dari spiritualitas, dan sebaliknya, spiritualitas adalah hanya bagian dari agama. Agama memiliki dua hal sekaligus; keyakinan dan praktek ajaran, sedangkan spiritualitas hanya berhubungan dengan kepecayaan pada aspek isoteris (dalam).

Pertanyaan selanjutnya adalah berkaitan dengan, pada bagian mana dari agama spiritualitas itu terdapat. Setiap agama, memiliki dua aspek utama, ialah spiritual dan ritual. Ritus adalah sebuah sebuah aktivitas yang selalu berulang-ulang, yang sangat sering merupakan simbol dari sesuatu yang dibutuhkan oleh sebuah masyarakat." Sedangkan spiritual, sebagaimana di depan adalah sesuatu yang abstrak dan intrinsik, karenanya, spiritualitas itu bisa dikatakan sebagai jantung dari agama, sesuatu yang memotivasi namun tidak nampak dalam pandangan luar dari sebuah agama atau ajaran tertentu. Karena spiritualitas itu merupakan pattern yang ada pada setiap agama, maka, bukan hanya di Barat, di Timur pun, banyak agama memendam khazanah spiritual, atau bahkań, sangat mungkin bahwa khazanaah spiritualitas dunia Timur lebih banyak dari pada di dunia Barat. India adalah sebuah contoh daerah spiritual yang oleh orang masih dicoba pengungkapannya hingga saat ini.

9Hinnels, 1997, h 668.

${ }^{10}$ Kennedy, h.155.

${ }^{11}$ Kirk, G.S., Myth (Cambridge: Cambridge University Press, 1978) h. 24. 
Topik: Fundamentalisme Agama dan Dahaga Spiritualitas Manusia Modern, Agus Triyanta

Dari situ nampaklah, apa itu spiritualitas, serta di manakah spiritualitas itu bertempat dalam tubuh sebuah agama. Namun, bagaimana sebuah spiritualitas itu akan diapresiasi oleh orang yang menjadi penganut dari sebuh agama, tentunya tergantung juga dengan seberapa besar hasrat dan dorongan para penganut tersebut untuk meraih spiritualitas tersebut. Di sinilah perlu diperbincangkan, bagaimana tingkat kebutuhan manusia terhadap spiritualitas itu.

Abraham Maslow, pakar sosiologi Amerika mengidentifikasi adanya lima tingkatan kebutuhan manusia, meliputi; kebutuhan fisik (phsyological needs), kebutuhan rasa aman (need for safety), kebutuhan akan cionta dan memiliki (need for love and belong), kebutuhan akan harga diri (need for esteem), serta yang terakhir, kebutuhan akan aktualisasi diri (need for self actualization). ${ }^{12}$ Meskipun secara umum, ungkap Turner ${ }^{13}$ dipersepsi bahwa kebutuhan internal itu adalah kebutuhan level kedua setelah kebutuhan eksteranal seperti makan, namun bukan berarti bahwa kebutuhan akan spiritualitas (sebagai bagian dari kebutuhan internal) itu bisa diabaikan. Sangat bisa jadi, sebagaimana fenomena yang terjadi di tengah berlimpahnya kebutuhan eksternal, orang modern justeru kian merindukan kedamaian, keamanan, dan berbagai bentuk kebutuhan internal. Ini sekaligus merupakan kritik atas teori konvensional tentang kesejahteraan sosial yang hanya diukur dengan parameter terpenuhinya (adequacy) akan kebutuhan eksternal.

Bila dicermati secara lebih mendalam, akan didapatkan juga bahwa kebutuhan akan spitualitas itu mengimplikasikan lahirnya berbagai macam sekte dalam berbagai agama. Hal itu dikarenakan, bahwa untuk memenuhi kebutuhan spiritualitas tersebut, manusia akan menempuh jalan, selain mencarinya dari para pembimbing atau counselor spiritual, juga yang paling sering, akan melakukan improvisasi atau modifikasi terhadap ajaran sebuah agama. Tak pelak, karena dorongan pemenuhan kebutuhan spiritualitas tersebut, akan muncullah berbagai macam sekte dan madzhab dalam berbagai agama, atau bahkan, orang akan membuat 'semacam' agama baru. Metode pemenuhan spiritualitasnya pun bisa menempuh berbagai' macam metode ritus; dari pensucian diri (purification), meditasi, ataupun kontemplasi, yang dengan itu akan bisa menghantarkan para pengikutnya pada status pengalaman dan perasaan mistis yang lebih tinggi. ${ }^{14}$ Maka kemudian, munculnya berbagai kelompok dan sekte kegamaan, yang sangat sering berbau fundamentalis, hanya salah satu bentuk yang paling umum untuk meraih spiritualitas.

\section{Kebutuhan akan Spiritualitas Memberikan Inspirasi Munculnya Gerakan Religius}

Modernisasi dan skularisasi telah memainkan peran yang utama dalam menyapu agama dari kehidupan manusia, bukan hanya pada perilaku mreka, namun juga pada cara-cara berpikir dan melakukan keputusan-keputusan atas berbagai masalah yang dihadapinya. Keduanya telah berhasil memindahkan manusia dari dunia yang banyak diwarnai hal-hal yang sakral menuju yang profan. Secara pasti, ilmu pngetahuan modern, kapitalisme dan rasionalisme

12Mann, Michael, Encyclopedia of Sociology (London: Macmillan Student, 1994) h. 259.

${ }^{13}$ Turner, Bryan S, The Penguin Dictionary of Sociology (London: Penguin Lane, 1984) h.142

${ }^{14}$ Hinnels, John, R, New Dictionary of Religions (Oxford: Blackwell Reference,1995) h. 72 . 
adalah komponen yang ikut mengakselerasi proses sekularisasi, yakni menurunnya fungsi agama, terpisahnya masyarakat dari agama, serta pergeseran dari yang sakral meunu yang sekular. ${ }^{15}$

Lantas, apakah efek dari ini semua?. Menurut Sorokin, relaita yang semacam ini akan mendorong terjadinya proses yang lain, yakni proses menuju pada apa yang disebut ideational system, yakni kehendak untuk menuju sistem yang benar-benar berbau supernatur, atau berlandaskan ketuhanan. ${ }^{16}$ Bentuk nyatanya adalah apa yang terjadi di dunia Barat, tumbuhnya berbagai macam gerakan agama, yang mencapai puncaknya tahun 1960-an, merupakan representasi dari reaksi atas menurunnya peran agama konvensional di negara Barat.Munculnya berbagai macam sekte dan kelompok yang baru itu, dipicu oleh berbagai problem yang bisa diformulasikan sebagai berikut:

1) Inovasi keagamaan terjadi ketika seseorang memiliki kebutuhan yang mendesak akan spiritualitas

2) Seseorang tidak bisa terpuaskan oleh institusi agama yang ada (telah mapan)

3) Sebagai akibatnya, seseorang akan keluar dari agama semacam di atas (pada no. 3)

4) Yang bersangkutan akan berupaya untuk mengembangkan metodenya sendiri untuk menumbuhkan spiritualitas dan ekspresi spiritualitas tersebut

5) Ini semua akan membawa/mengarah pada upaya pembentukan gerakan keagamaan yang baru. ${ }^{17}$

Dari formulasi di atas bisa dicatat dengan mudah bahwa gerakan keagamaan baru muncul dalam rangka menjawab pertanyaan yang substansial, yang berasal dari hati terdalam manusia modern. Yakni kebutuhan akan jawaban atas pertanyaanpertanyaan yang sangat substansial berkaitan dengan makna hidup, ketenangan hidup, dan pertanyaan-pertanyaan lain yang sejenisnya.

Berkaitan dengan bentuk gerakan agama dalam pembahasan di atas, secara general, ada dua model:

1. Pemberdayaan dan modifikasi dari agama yang telah ada

Ada kritik keras yang disuarakan oleh orang modern terhadap berbagai agama 'asli'. Permasalahan spiritualitas pada agama tradisional adalah bahwa spiritualitas yang ditawarkan terlalu bersifat individualistik, atau juga mungkin terlalu statis, terlalu banyak terfokus pada 'mempertahankan' sesuatu dari pada semangat kreativitas dan pembaharuan. Kritik lain yang dilontarkan adalah bahwa agara yang tradisional itu lebih banyak memperhatikan diri pribadi

15Nelson, Geoffrey, K, Cults, New Religion and Religion Creativity (London: Routledge \& Kegan Paul, 1987) h. 149-153. Pengertian yg hampir sama diberikan oleh banyak pakar, baik dalam bidang agama (religious studies) maupun oleh para sosiolog. Perter L.Berger juga menyatakan bahwa sekularisasi adalah sebuah proses di mana berbagai sektor dalam masyarakat dan budaya disingkirkan dari dominasi institusi dan simbol-simbol agama. (Berger, Perter L, The Sacred Canopy, Elements of a Sociological Theory of Religion [London-New York: Anchor Book Doubleday, 1990] h.107). Sedangkan Bryan Turner memberikan perincian aspek apa saja yg terkena sekularisasi itu, ialah, restraint, representasi, reproduksi dan registrasi. (Turner, Bryan $S$, Religion and Social Theory [London: Sage Publications, 1997] h.133).

${ }^{16}$ Nelson, h. 147.

${ }^{17}$ Nelson, h. 109.

18H-linnels, 1997, 677.

${ }^{19}$ Hinnels, 1995, h.171.

${ }^{20}$ Nelson, h. 151. 
dan aspek-aspek ke dalam diri (inward) pribadi, disertai dengan penolakan terhadap materi dan kesenangan konsulmerisme, dari pada memberikan perhatian yang seimbang pada keduanya..$^{18}$

Itu salah satu aspek alasan, mengapa sebuah agama itu dimodifikasi. Sebagai misal, pada tahun 1960-an, kehadiran dan keanggotanaan gereja di Amerika Serikat naik, sedangkan di Inggris mengalami penurunan. Fenomena ini kemudian memancing terjadinya diskusi di seputar, faktor apakah yang menjadi penyebab dari fenomena tersebut. Berger dan Herberg ${ }^{19}$ menyatakan bahwa gereja-gereja di Amerika telah mampu survive dengan cara 'menampilkan wajah yang tersekularisasi' dan menawarkan agama sebgai sebuah 'gaya Amerika' dari pada menawarkan agama sebuah. sebuah ketaatan pada tingakatan yang lebih spiritual dari agama Kristen.

Sangat mungkin, bahwa alasan para teolog itu benar, yakni bahwa mereka itu tidak merusak agama, tetapi hanya mengembangkan agama, atau tradisi dari agama untuk menjadi lebih perhatian kepada dunia nyata. ${ }^{20}$ Bukankah, Plato pemah memberikan kesimpulan yang menarik tentang ini, menurut Plato, ada sebagian orang yang bisa melihat kebenaran secara lebih baik daripada' orang lain melihatnya. Karena itulah orang tertentu bisa melihat lebih terhadap apa yang orang kebanyakan hanya melihatnya sebagai bayangan yang berubah (distorted shadow). ${ }^{21}$ Itulah mengapa, dalam realitanya, ada orang-orang tertentu yang sudah cukup puas dengan sebuah 'model' agama, namun ada orang lain yang belum puas dengan bentuk agama tersebut.

Inilah yang kemudian, orang akan mencari sesuatu yang lebih memuaskan dari pada agama yang telah dijumpainya tersebut. Sehingga orang akan merenovasi dan memodifikasi agama yang lama (mapan) sebagai upaya untuk memenuhi tuntutan kebutuhan diri. Orang akan memodifikasinya menjadi sebuah model yang dipangan sesuai dengan kebutuhan spiritualnya. Mungkin orang lain akan mengatakan ini sebagai sebuah tindakan bid'ah (heresy), namun fakta yang terjadi memang demikian, inovasi bukan hanya ditepakan pada teknologi, namun dalam tingkat tertentu, agama telah menjadi obyek inovasi.

2. Membuat atau Mencari Agama atau Sekte Spiritual Baru

Karena ketidakpuasan terhadap agamaagama yang telah ada, orang modern cenderung untuk mencari agama-agama atau sekte-sekte spiritual yang baru. Dan, sebagaimana riset yang teiah banyak dilakukan para sosiolog, ada berbagai macam agama dan sekte spiritual yang mampu menarik perhatian orang-orang modern yang sedang berada dalam kehausan spiritualitas.

Agama-agama di Timur, siap menuai panen ketika terjadi antusiasisme spiritualitas di dunia Barat pada awal dan pertengahan 1970-an. Banyak gerakan-gerakan agama baru di USA yang tumbuh dan meraih proporsi pengikut dalam level nasional, dan secara cepat menyebar ke Eropa. Dalam saat yang bersamaan, gerakan-gerakan yang telah berdiri sebelumnya di Inggris dan di Eropa daratan, dengan segera mendirikan cabang-cabang di Amerika Utara. Di akhir 1990, di Amerika sendiri saja ada lebih dari 1000 sekte Kristen, sedangkan di Inggris ada 604 gerakan keagamaan, dan di seluruh Eropa, ada sekitar 1.317 gerakan keagamaan. ${ }^{22}$ Bukan hanya monopoli Eropa dan Amerika Utara saja krisis spiritualitas dan maraknya sekte terjadi, saat ini, tidak kurang dari sekitar

\footnotetext{
21Kuper, h. 733.

${ }^{22}$ Hinnels, 1997, h. 599.
} 
Topik: Fundamentalisme Agama dan Dahaga Spiritualitas Manusia Modern, Agus Triyanta

3000 gerakan keagamaan di Amerika Serikat, dan sekitar 12000 di Jepang. ${ }^{23}$

\section{Fundamentalisme sebagai Pemenuhan Spiritualitas}

Terkadang, gerakan-gerakan baru keagamaan, sebagai bentuk dari upaya penyembuhan dahaga spiritualitas itu, menempuh upaya yang bisa dipandang sangat ekstrem, yang akan memberikan nuansa fundamentalisme, yang menganggap bahwa sekte itulah satu-satunya institusi yang ajarannya paling bisa menjawab dan memenuhi kehausan spiritualitanya, yang karenanya, akan terjebak pada tindakantindakan yang terkadang anti-sosial. Orang tidak akan mempedulikan itu semua selama itu merupakan bagian dari ajaran sekte atau aliran yang dianutnya itu. Dalam benaknya, cara dan tindakan itu adalah 'panggilan suci' yang kebenarannya harus dipegang teguh dan kemudian ditunaikan. Sangat sering gerakan itu menimbulkan bahaya bagi orang lain. Sangat mungkin juga, aktivitasnya nampak sangat kejam dan tidak manusiawi. Ada beberapa bukti yang bisa dicatat atas thesis semacam ini: ${ }^{24}$

22 Maret, 1997, di San Diego, 39 anggota dari Heaven's Gate bunuh diri dengan cara meminum racun (alkohol dicampur dengan Phenobarbitol), mereka, dalam cara bunuh dirinya pun mengikuti aturan yang.telah ditetapkan oleh agama sekte itu.

- 1995 di Tokyo, dengan dikomando oleh Shoko Asahara, sebagai pemimpin sekte, para anggota dari Aum Shinri $K$ yo telah membunuh 12 orang dengan menggunakan gas sarin, melukai 5.500 orang di Subway di Tokyo. Sekte ini cukup menarik banyak pengikut, tidak kurang dari 10.000 kawula muda di Jepang dan 30.000 kaum muda di
Rusia telah bergabung dengan gerakan ini.

口 1994 di Lousane, Switzerland, 48 anggota dari sebuah sekte yang menamakan diri sebagai Sun Temple bunuh diri bersama, posisi diatur seperti konfigurasi sinar matahari.

口 1993 di Texas, 82 anggota dari seklte Branch Davidian melakukan bunuh diri, termasuk pemimpinnya, David Koresh. 1978 di Jones Town Jungle, Guyana, 914 anggota dari sekte yang bernama People's Temple bunuh diri dengan meminum racun menuruti perintah pemimpinnya, yang bernama Jim Jones.

Fenomena seperti itu tentunya membutuhkan pemahaman yang multi-perspektif untuk memahami apa maksud dan tujuan dari tindakan mereka itu. Namun paling tidak, fenomena itu telah memperlihatkan bahwa manusia itu sangat membutuhkan spiritualitas, yang demi pemenuhannya mereka akan rela melakukan apa saja meskipun bertentangan dengan berbagai prinsip kemanușiaan. Dan itulah sebagian dari cermin fundamentalisme.

\section{Kesimpulan}

Dari pembahasan di atas, bisa didapatkan sebuah alur yang jelas, bahwa sekularisme dan kehidupan yang sangat materialistis (termasuk di sini rasionalisme) di zaman modern ini telah menyumbangkan jasa yang sangat besar bagi tersapunya peran agama dalam kehidupan. Dalam masyarakat yang telah tersekularisasi, bukan hanya

${ }^{23}$ Republika, 19 Mei 1995, Kedaulatan Rakyat, 12 April, 1996.

${ }^{24}$ Fakta kasus ini dirangkum dari berbagai sumber, Hinnels, 1995, Republika, 19 Mei 1995, 11 Oktober 1996, Kedaultan Rakyat, 12 April 1997). 
kehidupan politik, namun dalam seluruh tingkah laku tidak lagi berada pada kontrol agama. Agama, benar-benar telah dibersihkan dari kehidupan manusia, atau dalam bahasa Nietzsche, "Tuhan telah mati". ${ }^{25}$

Tenyata sekularisasi juga bukan solusi, dia telah menghadirkan sebuah problem baru, ialah ketidakpastian hidup, ketiadaan sebuah sistem nilai yang dipegang teguh, ketiadaan apa yang dalam pembahasan di muka diistilahkan dengan spiritualitas. Kegersangan spiritualitas akhirnya melanda manusia modern, sebuah krisis lantas terjadi. Kegersangan inilah yang akhirnya menggiring pada segala macam upaya rediscovery (penemuan ulang) terhadap spiritualitas, lewat berbagai agama dan tradisi. Spiritualitas baru itulah yang kemudian diburu dan dicari. Orang menemukannya dengan berbagai cara dan di berbagai macam aliran dan sekte spiritual. Bisa jadi karena kuatnya dorongan dahaga spiritualitas itulah, maka kemudian, setelah seseorang berada dalam aliran dan ajaran tertentu, dia akan menolak berbagai cara dan model kehidupan modern yang telah mensekulerkannya, berbagai kehidupan dunia bisa dianggap sebagai ancaman yang akan mengantarkan manusia pada krisis spiritualitas. Jadilah, para penganut aliran tertentu tersebut memiliki sebuah 'world view' atau pandangan dunia tertentu, yang biasanya sangat eksklusif. Pandangan mereka akan sangat berbeda dengan pandangan orang awam, dan mereka menganggap sesuatu sebagai 'ancaman' yang itu bagi kebanyakan orang tidak akan dianggap sebagai ancaman. Sebaliknya, banyak di antara berbagai aliran - termasuk di atasyang menginginkan terciptanya sebuah tata kehidupan yang baru sebagi pengganti dari kehidupan modern yang 'merusakkan' manusia.

Dengan alur semacam itu, maka tidak mustahil apabila kemudian, para penganut aliran tersebut akan menjadi apa yang diistilahkan sebagai fundamentalis, yang perilakunya bisa bersifat asosial, melawan 'kemewahan dunia' serta menghancurkan berbagai apa yang saja yang mereka nilai melawan keyakinan mereka dan menjadi agen sekularisasi.

Fundamentalisme, kalau begitu, bukanlah masalah yang sederhana, gejalanya selalu massif dan laten. Namun, berbagai upaya bisa dilakukan, antara lain, memberikan apresiasi terhadap partikularitas sebuah ajaran, tidak menidasnya atau 'membungkam'nya. Dialog juga sangat penting untuk mewujudkan, selain. pemahaman yang komprehensif dan lapang, juga memberikan kesempatan untuk membangun sebuah basis etika yang harus disadari dan dipegang bersama.

\section{Bibliography}

Azra, Azumardi, "Karen Amstrong: Islam dalam Perspektif Empati', dalam Tempo, 30 Desember 2001.

Berger, Perter L,. 1990. The Sacred Canopy, Elements of a Sociological Theory of Religion, London-New York: Anchor Book Doubleday.

Goenawan Mohamad, 'Oklahoma', dalam, Tempo, 20 Januari 2002.

Haralambos, Michael \& Holborn, Martin. 1999. Sociology. Themes and Perspectives. London: Collins Educational.

${ }^{25}$ Nietzsche, dalam Ingraffia, Brian D, Postmodern Theory and Biblical Theology (Cambridge: Cambridge University Press, 1995) h. preliminaries. 
Topik: Fundamentalisme Agama dan Dahaga Spiritualitas Manusia Modern, Agus Triyanta

Hinnels, John, R,. 1995, New Dictionary of Religions, Oxford: Blackwell Reference.

Hinnels, John $R_{1}$. 1997, A New Handbook of Living Religions, Oxford: Bluckwell Publisher.

Ingraffia, Brian D. 1995, Postmodem Theory and Biblical Theology, Cambridge: Cambridge University Press.

Kennedy, Richard. 1984, The Dictionary of Beliefs, London: Ward Lock Educational.

Kirk, G.S., Myth. 1978, Cambridge: Cambridge University Press.

Kuper, Adam, \& Kuper, Jessica.1996, The Social Science Encyclopedia, LondonNew York: Routledge.

Madan,T.N., 1998, 'Characteristics of Sikh Fundamentalism' dalam Beckerlegge,
Gwilym, The World Religious Reader, London: Routledge.

Mann, Michael. 1994, Encyclopedia of Sociology, London: Macmillan Student.

Nelson, Geoffrey, K, Cults. 1987, New Religion and Religion Creativity, London: Routledge \& Kegan Paul.

Turner, Bryan S,.-1984, The Penguin Dictionary of Sociology, London: Penguin Lane.

Turner, Bryan S.. 1997, Religion and Social Theory, London: Sage Publications.

Kedaulatan Rakyat, 12 April 1997.

Republika, 19 Mei, 1995.

Republika, 19 Mei 1995.

Kedaulatan Rakyat, 12 April, 1996. 